\title{
The Influence of Foreign Direct Investment on the GDP Progression of Pakistan
}

\author{
Muhammad Aslam Javed \\ Universiti Utara Malaysia \\ aslam.javed86@gmail.com
}

\begin{tabular}{ll}
\hline ARTICLEDETAILS \\
\hline History & \\
Received & $:$ February \\
RevisedFormat & $:$ March \\
Accepted $\quad:$ April \\
\hline
\end{tabular}

Keywords :

Exchange rate, Foreign direct

investment, Consumer price

index, Trade Openness, Energy

Imports and Cointegratio

\begin{abstract}
S
The Foreign Direct Investment (FDI) inflows play very important role in the economic development of the beneficiary country. The objective of this study is to check the impact of exchange rate (and other variables like Foreign Exchange Rate, Consumer price index, Trade Openness, and Energy Imports) on foreign direct investment in Pakistan by taking annual data from the period 1999-2013 (Monthly Basis).By using Descriptive ,Correlation and regression, the effect of Consumer Price Index, exchange rate, trade openness, energy imports on Foreign Direct Investment (FDI) of Pakistan. The study guide the foreign investor and to categorize the factors, that can affect the Foreign Direct Investment (FDI), while investing in Pakistan.
\end{abstract}

(C2020 STIM Lasharan Jaya Makassar

\section{INTRODUCTION}

Foreign Direct Investment (FDI) in Pakistan is one of the major external sources of funding to meet obligations of resources gap and goal achievement. FDI has played a vital role in the economic growth of Pakistan. FDI contributed significantly in the human resources development, capital formation and organizational and managerial skills of the people in the country. Total foreign investment was $\$ 6.0$ billion, of which FDI amounted to $\$ 4.16$ billion in the year 2007.According to an endogenous growth model of Lucas (1988) and Romer (1986), an assumption of increasing and constant returns to capital was the cause of permanent addition in growth rate. Furthermore according to Romer, human capital also played vital role in growth procedure. The essantioal factor for the growth of any developing economy is investment. Therefor investment in the asset of the economy will play an essential role in the growth (Kappel et al.,2004). Pakistan is a developing country which seek capital investment from foreign capital inflow for the GDP growth and to finacnce saving investment gap (Siddiqui and Kemal,2006). Political unstability looses the confidence of Investor to invest in host country (Mushtaq et al 2012, Khan 1997). So Political stability and stable exchange rate are important to attract investor to invest (Kiyota \& Urata 2002). Therefore, this study is conducted to examine the impact of exchange rate and other variables such as: Consumer price index , Energy Import, Trade openness on foreign direct investment in Pakistan for the period 1999-2013.

\section{Background of the Study}

When a Company invest in another country it is called Foreign Direct Investment (FDI). Foreign Direct Investment (FDI) inflows in speed up its growth process. There are many macroeconomic variables which have significant impact on Foreign Direct Investment (FDI) inflows like Exchange rate, interest rate, Money supply, tariff rate, human capital, inflation, stock prices, terrorism, political instability and economic instability etc. Relationship of Exchange rate and Foreign Direct Investment have attracted the resecher's attention in previous decades. Exchage rate stability is one of the main issue for researchers Exchange 
rate effect Investment in two different ways. When exchange rate depreciates, A floating exchange rate determined by the supply and demand forces in the market. Mostly floating exchange rate is preferred by the economies than the fixed exchange rate. Floating exchange rate enables the country to justify the impact of shocks and foreign business cycles and also manages the balances of payment crisis.Exchange rates policies are useful to increase exports and compete international market. Future predition and control of money supple is not guaranted if exchange rate is unstable. Resolute exchange rate creates disturbance in the trade cycle while flexible exchange rates are adopted by democratic countries (Michael and David ,2001).

\section{Research Questions / problem}

Many risks are related to Foreign Direct Investment (FDI) like Political \& Economic instability, law and order situation, stock market situations, prices, inflation, interest and exchange rate instability and terrorism etc. it is necessary for the foreign investor to identify and manage the risk because there is no reward without risk and higher risk leads the greater reward.

1) Does exchange rate effect Foreign direct Investment in Pakistan?

2) What are the Variables cause a rise of Foreign Direct Investemnt in Paksitan?

3) Whether Foreign Direct Investment (FDI) is negative or positively affected by depreciation or appreciation of the exchange rate in Pakistan during the study period 1999 to 2013 ?

These are the questions which are to be discussed in this research.

\section{Objective of the study}

The objectives of this study are:

1) To find the relationship of the exchange rate and other variables on Foreign Direct Investment (FDI) inflows of Pakistan through Cointegration Analysis technique.

2) To guide the foreign investor to categorize the factors, that can affect the Foreign Direct Investment (FDI), while investing in Pakistan.

3) To Help policy makers to formulate the macroeconomic policies.

\section{Rationale of the Study}

Investment becomes risky and investor loose confidence to invest in host country due to political instability (Mushtaq et al 2012, Khan 1997). Political stability and stable exchange rate are important to attract investor to invest (Kiyota \& Urata 2002). Democratic countries have high Growth rate as compare to non-democratic countries, so democracy attracts Foreign Direct Investment (FDI) in the host country (Jenny A. Minier 1998, Khalid et al, (2010)) but Muhammad Imtiaz et al (2011) claimed that non democratic Govt is better growth of Pakistan.

\section{LITERATURE REVIEW}

Foreign direct investment is biggest support for the economic development of any country. Various studies have been done to investigate the impact of exchange rate and other variables (inflation, trade openness, Energy imports) on Foreign Direct Investment (FDI) in Pakistan by taking annual data from 1999 to 2013.

\section{Foreign Direct Investment (FDI) and its determinants}

The role of Foreign Direct Investment (FDI) in the growth of an economy is very essential because it is the cause of new technology, skill and foreign funds to the beneficiary country (Nasir \& Hassan 2011). Foreign Direct Investment (FDI) plays an important role to overcome this shortage of Resources (Sawyer et al, 2006). Foreign Direct Investment (FDI) inflows are 
affected by the various factors in the host country, such as Government policies, macroeconomic factors, (Nasir and Hassan 2011).

Talat et al. (2013) used the regression analysis and ARMA model to check the impact of Various factors for Foreign Direct Investment (FDI) inflows in Pakistan. electricity generation, exchange rate, inflation rate (insignificant), Trade openness had positive impact on Foreign Direct Investment (FDI) inflows. Onuorah et al. (2013) used Co-Integration Technique to check long run relationship between macroeconomics variables (GDP, inflation rate, Money supply) on Foreign Direct Investment (FDI) in Nigeria. The result showed GDP is negatively related to Foreign Direct Investment (FDI) while all other variables have positive influences on FDI in Nigeria.

Chingarange Anna et al. (2012) used regression test to find out the causes of low Foreign Direct Investment (FDI) in Zimbabwe and reported that positive relation exist among interest rate (insignificant), inflation rate (insignificant), GDP growth rate, corporate taxes with Foreign Direct Investment (FDI) inflows while risk factors, labor cost and exchange rate (insignificant) are negatively related with Foreign Direct Investment (FDI) in Zimbabwe.Benjamin et al. (2012) empirically proved through difference-in-difference approach that real exchange rate is appreciated due to democratization by taking data of countries from 1980-2007. So the impact of democratization, on the exchange rate is positive.

Iqbal and Ali (2011) investigated the exchange rate effect on Foreign Direct Investment (FDI). The ADF test used to check the stationary of the variables and OLS regression analysis used to investigate the effect of macroeconomic variables on Foreign Direct Investment (FDI).

Edward and Charles (2011) reported the relationship between Exchange Rat and FDI by using Ordinary Least Square (OlS) and Co-integration Techniques. They Concluded weak relation between FDI inflows and Exchange Rate in Ghana..Mehdi et al. (2011) used GARCH model to proved the relationship of exchange rate uncertainty on domestic investment and reported a negative relation exists. M. Arshad and Shujaat Ali (2011) showed the impact of Foreign Direct Investment (FDI) on GDP (growth) of Pakistan by using co-integration and Granger causality testing by using data from 1981 to 2008. The results evidence the long run unidirectional causality exists from GDP to (FDI) and in short run bi-directional causality exist between them.

Bakhtiar et al. (2010) test factors affect the Foreign Direct Investment (FDI) in Pakistan, time series annual data for the period 1971-2008was used. The error correction model and regression analysis was used to check the effect of independent variables [like Debt service (percentage of GNP), Trade openness (exports + imports), current account balance, gross fixed capital formation, inflation rate, GDP at factor cost] on Foreign Direct Investment (FDI) inflows of Pakistan. The results reveal that trade openness, gross fixed capital formation, inflation, debt service has a positive impact on Foreign Direct Investment (FDI) while the current account balance has negative impact on foreign direct investment (FDI).

Stuart et al. (2007) by using the Error Correction Methodology on the panel data of OECD countries and found short run and long run, the effect of depreciation of home currency was negative in overall investment in the majority of the sectors of the country.

Ismail and Burak (2007) find out the determinants of Foreign Direct Investment (FDI) in seventeen countries by panel data analysis from the period January 1989 to April 2008. The explanatory variables used in the study were Labour cost,, market size, trade rate, inflation rate, real interest rate, domestic investment and foreign direct investment in the previous period. It was found from empirical analysis that The relationship of inflation rate with Foreign Direct Investment (FDI) was found to be negative and interest rate, market size, trade rate and Foreign Direct Investment (FDI) in the previous period positively related to (FDI). Hakro and Ghumro (2007) found the determinants of Foreign Direct Investment (FDI) :

(1) The investment environment improving factors (openness of economy, liberalization)

(2). Factors realted to Cost (Wage rate, Interest rate, Foreign exchange rate). 
(3) Development strategy of country and structural shocks (political risk indicator and economic stability)

(4). Macroeconomic factors (Output growth, Market size, Human capital, quality of infrastructure. Olga (2006) determin the investment and exchange rate volatility relationship in Chile from 1979-2000. He analyse that there is negative relation exists between Investment and Exchange Rate.

Philippi et al. (2006) Examined that the instability of exchange rate decreases the growth in those countries which are financially less developed and have no significant effect in those countries which are financially developed. And showed the negative effect of exchange rate on investment of domestic credit market. Masayuki and Ivohasina (2005) checked 1980-2001 for the exchange rate, land prices, GDP, Law \& regulation to check which factors effecting Foreign Direct Investment (FDI) in Japan. He found significant relationship between Exchange rate, Price Movement, Market size and cost of establishing green field's plants and Foreign Direct Investment (FDI) inflow for Japan and market size positively while volatility of exchange rate, price movements negatively related to Foreign Direct Investment (FDI).

\section{Proposed Model}

Consumer Price Index, exchange rate, trade openness, energy imports are independent variable while Foreign Direct Investment (FDI) is dependent variable. The study is conducted by taking annual data from 1999-2013.

$$
\mathbf{Y}=\alpha+\beta_{1}(\mathrm{CPI})+\boldsymbol{\beta}_{2}(\mathrm{ER})+\boldsymbol{\beta}_{3}(\mathrm{OP})+\boldsymbol{\beta}_{4}(\mathrm{EI})
$$

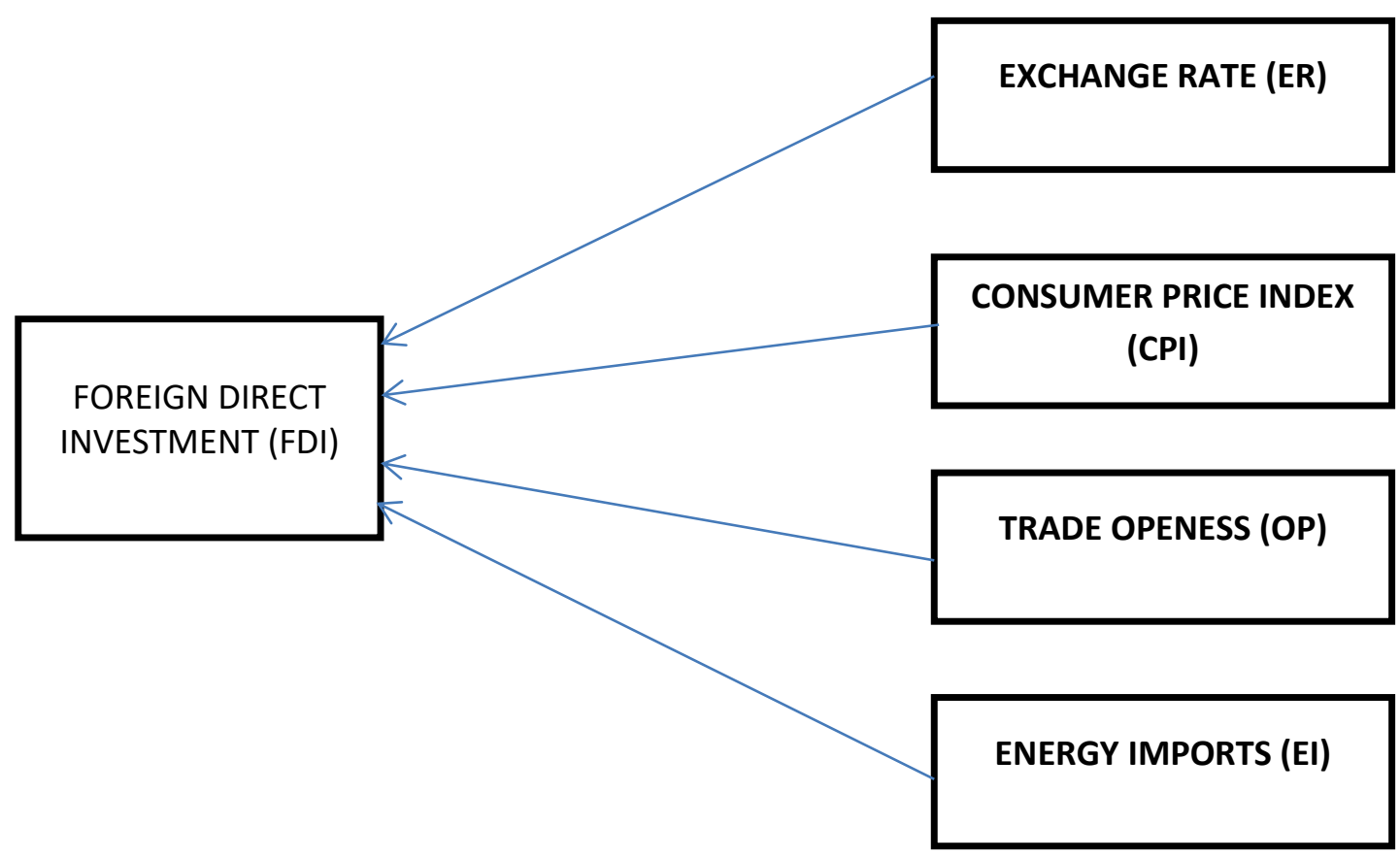

\section{Hypothesis of the study}

The Hypotheses of this research are as follows:

- $\mathrm{H}_{0}$ : There is no significant impact of Foreign Exchange Rate, Consumer Price Index , Trade Openness and Energy Import on Foreign direct investment in Pakistan..

- $\mathrm{H}_{1}$ : There is significant impact of Foreign Exchange Rate on Foreign direct investment in Pakistan.. 
- H2: There is a significant impact of consumer price index on Foreign direct investment in Pakistan .

- H3: There is significant impact of trade openness, Energy imports, on Foreign direct investment of Pakistan.

\section{RESEARCH METHODOLOGY}

\subsection{Theoretical Frame}

The effect of Consumer Price Index, exchange rate, trade openness, energy imports on Foreign Direct Investment (FDI) of Pakistan is investigated by using Co-integration , Unit root Test and regression analysis technique [as used by: Talat et al. (2013), Mushtaq et al. (2012), Aqeel and Nishat (2004), Edward and Charles (2011), Kiyota and Urata (2002), Nasir and Hassan (2009), Mahmood and Ali (2011), Hakro and Ghumro (2007), Shamsuddin (1994), and Shah and Ahmad (2003)]. Time series data for the period 1999-2013 (Monthly Basis) has been used in this study.

\subsection{Model Specification and justification of variables}

To check the dependence of Foreign Direct Investment (FDI) on Consumer Price Index, exchange rate, trade openness, energy imports in Pakistan, a model has been developed through theoretical and empirical literature. Aqeel and Nishat (2004),

\subsubsection{Dependend Variable Foreign Direct Investment (FDI)}

The dependent variable used in this study is foreign direct investment in Pakistan. The previous study has taken the Foreign Direct Investment (FDI) as: Foreign Direct Investment (FDI) growth rate (Mushtaq et al. 2012), Real Foreign Direct Investment (FDI) annual inflows (Shah and Ahmad, 2003), (Nasir and Hassan, 2009), Growth in Foreign Direct Investment (FDI) annual inflows (Aqeel and Nishat, 2004), Per capita Foreign Direct Investment (FDI) (Shamsuddin 1994). This study will take Foreign Direct Investment (FDI) as Foreign private investment (direct) due to its availability.

\subsubsection{Independent Variables}

In the light of above literature the following Independent variables that can affect the Foreign Direct Investment (FDI) to Pakistan have taken:

\subsection{2 (I) Exchange Rate (ER)}

The Real effective exchange rate of Pakistan in terms of US \$ is taken as independent variable (Aqeel and Nishat 2004, Mushtaq et al. 2012, Nasir and Hassan 2009). Most studies showed exchange rate devaluation in host country attract the Foreign Direct Investment (FDI) inflows [Mushtaq et al.(2012), Goldberg S-Linda (2007), Shah and Ahmad (2003), Love and Hidalgo (2000) and Froot and Stein (1991)].

\subsection{2(II) Trade Openness (OP)}

The openness of trade plays a potential role to increase the Foreign Direct Investment (FDI) inflows. Trade openness will be measured by exports + imports (Bakhtiar et al. 2010). Previous studies also used (Total trade/ GDP) as a proxy for Trade openness. [Hakro \& Ghumro, 2007, Haufbauer et al, 1994, Ryck Eghem 1998, Edward \& Charles 2011 , Matthias 2003, Asante et al, 2000 ]. While Mushtaq et al (2012) used exports + imports / GDP and Talat et al. 2013, used ratio of exports to imports as a proxy for Trade openness. The literature suggests positive relationship between Trade openness and Foreign Direct Investment (FDI) inflows (Ismail \& Burak 2007).

3.2.2(III) Consumer Price Index (CPI)

In home country the effect of inflation on Foreign Direct Investment (FDI) inflows is negative. (Hakro and Ghumro 2007, Sayek selin 1999, Ismail and Burak (2007)). The annual average 
inflation rate was used as a proxy for economic stability by Hakro \& Ghumro (2007). This study will take the consumer price index, all items.

Some studies also suggest a positive relation between Inflation and Foreign Direct Investment (FDI) because due to higher prices the foreign investor earns abnormal profits in the host country. (Bakhtiar et al. (2010), Onuorah et al. (2013), Talat et al. (2013), Chingarange Anna et al, (2013).

\subsection{2 (IV) Energy imports (EI)}

According to Khan 1997, one of the causes of low Foreign Direct Investment (FDI) in Pakistan is week infrastructure facilities (Power, water supplies and telecommunication). Mushtaq et al. (2012) and Shamsuddin (1994) used energy imports (percentage of total merchandise exports) to measure the energy availability in Pakistan and they showed that energy import negatively related to Foreign Direct Investment (FDI) inflows in Pakistan but the result was insignificant. This study will use the value of Oil imports as proxy for energy imports.

\subsection{Expected direction of the variables}

In the light of literature studies, the following table shows the exogenous variables and their expected sign with the dependent variable (foreign direct investment, Foreign Direct Investment (FDI)) of Pakistan.

\subsection{Data Description and Sources}

This study is based on secondary data. The data on Foreign Direct Investment (FDI) is taken from handbook of statistics on Pakistan economy, while data relating to Consumer Price Index, exchange rate, trade openness, energy imports is taken from (IFS) International financial statistics for the period 1999-2013 (Monthly Basis).

\subsection{Econometric models and Estimation Techniques}

It is well known that many economic time series are difference stationary. In general, a regression involving the levels of these I(1) series will produce misleading results, with conventional Wald tests for coefficient significance spuriously showing a significant relationship between unrelated series (Phillips 1986).

Engle and Granger (1987) note that a linear combination of two or more I(1) series may be stationary, or I $(0)$, in which case we say the series are cointegrated. Such a linear combination defines a cointegrating equation with cointegrating vector of weights characterizing the longrun relationship between the variables.

We will work with the standard triangular representation of a regression specification and assume the existence of a single cointegrating vector (Hansen 1992b, Phillips and Hansen 1990). Consider the $n+1$ dimensional time series vector process $\left(y_{t}, X_{t}^{\prime}\right)$, with cointegrating equation

$$
\mathrm{y}_{\mathrm{t}=} \mathrm{X}_{\mathrm{t}}^{\prime} \beta+\mathrm{D}^{\prime} \mathrm{Y}_{1}+\mu_{1}
$$

where $D_{t}=\left(D_{1 t} \quad, D_{2 t}\right)^{\prime}$ 'are deterministic trend regressors and the $n$ stochastic regressors $X_{t}$ are governed by the system of equations

$$
\begin{aligned}
X_{t} & =\Gamma_{21}^{\prime} D_{1 t}+\Gamma_{22}^{\prime} D_{2 t}+\epsilon_{2 t} \\
\Delta \epsilon_{2 t} & =u_{2 t}
\end{aligned}
$$


The $p_{1}$-vector of $D_{1 t}$ regressors enter into both the cointegrating equation and the regressors equations, while the $p_{1}$-vector of $D_{2 t}$ are deterministic trend regressors which are included in the regressors equations but excluded from the cointegrating equation (if a nontrending regressor such as the constant is present, it is assumed to be an element of $D_{1 t}$ so it is not in $\left.D_{2 t}\right)$.

Following Hansen (1992b), we assume that the innovations $\mu_{t}=\left(\mu_{1 t}, \mu_{2 t}\right)^{\prime}$ are strictly stationary and ergodic with zero mean, contemporaneous covariance matrix $\sum$, one-sided long-run covariance matrix $\boldsymbol{\Lambda}$, and covariance matrix $\boldsymbol{\Omega}$, each of which we partition conformably with $\mu_{t}$.

$$
\begin{aligned}
\Sigma= & E\left(u_{t} u_{t}^{\prime}\right)=\left[\begin{array}{ll}
\sigma_{11} & \sigma_{12} \\
\sigma_{21} & \Sigma_{22}
\end{array}\right] \\
\Lambda= & \sum_{j=0}^{\infty} E\left(u_{t} u_{t-j^{\prime}}\right)=\left[\begin{array}{ll}
\lambda_{11} & \lambda_{12} \\
\lambda_{21} & \Lambda_{22}
\end{array}\right] \\
\Omega= & \sum_{j=-\infty}^{\infty} E\left(u_{t} u_{t-j}^{\prime}\right)=\left[\begin{array}{ll}
\omega_{11} & \omega_{12} \\
\omega_{21} & \Omega_{22}
\end{array}\right]=\Lambda+\Lambda^{\prime}-\Sigma
\end{aligned}
$$

It is well-known that if the series are cointegrated, ordinary least squares estimation (static OLS) of the cointegrating vector $\beta$ is consistent, converging at a faster rate than is standard (Hamilton 1994). One important shortcoming of static OLS (SOLS) is that the estimates have an asymptotic distribution that is generally non-Gaussian, exhibit asymptotic bias, asymmetry, and are a function of non-scalar nuisance parameters. Since conventional testing procedures are not valid unless modified substantially, SOLS is generally not recommended if one wishes to conduct inference on the cointegrating vector.

\section{RESULTS AND DISCUSSIONS}

\subsection{Data analysis}

The objective of this study is to check the impact of Consumer Price Index, exchange rate, trade openness, energy imports on foreign direct investment in Pakistan by taking annual data from the period 1999-2013 (Monthly Basis). This study employed the methodology e.g. Descriptive Corelation ,Regression, Co-integartion, Unit Root Test.

This chapter will present and interpret the results obtained from these tests.

Table 1 : Findings direction of variables from the period 1999-2013 (Monthly Basis)

\begin{tabular}{|l|l|l|l|}
\hline Variables & $\begin{array}{l}\text { Expected } \\
\text { sign }\end{array}$ & $\begin{array}{l}\text { Study } \\
\text { Findings }\end{array}$ & Prob. \\
\hline Exchange rate (ER) & + or - & + & Significant \\
\hline Openness (OP) & + & + & Significant \\
\hline Inflation (CPI) & + or - & - & Insignificant \\
\hline Energy imports(EI) & - & + & Significant \\
\hline
\end{tabular}


Table 2 : Expected direction of variables from the period 1999-2013

\begin{tabular}{|l|l|l|}
\hline Variables & Description & $\begin{array}{l}\text { Expected } \\
\text { direction }\end{array}$ \\
\hline $\begin{array}{l}\text { Exchange rate } \\
(\text { ER) }\end{array}$ & Real effective exchange rate (ER: Rs=1 US\$) & + or - \\
\hline Openness (OP) & Openness (exports,BOP + imports, BOP) & + \\
\hline $\begin{array}{l}\text { Consumer Price } \\
\text { Index (CPI) }\end{array}$ & Consumer prices index, all items & + or - \\
\hline $\begin{array}{l}\text { Energy imports } \\
\text { (EI) }\end{array}$ & Value of oil imports & - \\
\hline
\end{tabular}

\subsection{Descriptive statistics and Correlation analysis}

First of all, descriptive statistics of the variables will have been made on the data of the variables from the period 1999 to 2013 (Month Basis) to check the normality of the variables. The mean, Kurtosis, standard deviation and skewness will be checked and interpreted of all the variables series. Further, in order to determine the correlation between the variables, a correlation matrix will be obtained.

\section{2 (I) Descriptive Statistics}

The descriptive statistics of the variables Foreign exchange,Consumer price index,Trade opennes and energy import and foreign direct investment) are made in order to check the normality of variables..

The descriptive statistics shows that all the four variables i.e. Foreign Direct Investment (FDI), FE, CPI, OP and EI has lot of variability in terms of minimum and maximum values. Due to the difference between minimum and maximum values, the range statistics parameter "Skewness" exceed beyong 1 for Foreign Direct Investment (FDI) which further shows that the data is skewed and not normally distributed. However, for rest of the parameters, the values for skewness between -1 to +1 which is an indication or normal distribution of data for FE, CPI, OP and EI.

Table 3 - Descriptive

Sample: 1999M01 2013M12

\begin{tabular}{lccccc}
\hline \hline & FDI & OP & EI & CPI & FE \\
\hline \hline Mean & 160.6728 & 32.60293 & 112.8638 & 129.2486 & $8.73 \mathrm{E}+09$ \\
Median & 98.40000 & 30.68381 & 109.7850 & 107.7210 & $1.01 \mathrm{E}+10$ \\
Maximum & 1262.900 & 55.47514 & 249.4000 & 227.0690 & $1.56 \mathrm{E}+10$ \\
Minimum & -35.50000 & 16.85309 & 22.47000 & 73.39701 & $1.06 \mathrm{E}+09$ \\
Std. Dev. & 191.7802 & 10.21660 & 59.87252 & 52.33650 & $4.24 \mathrm{E}+09$ \\
Skewness & 2.716162 & 0.353600 & 0.311342 & 0.658477 & -0.629058 \\
Kurtosis & 12.11934 & 1.902471 & 1.785992 & 1.900361 & 2.201304
\end{tabular}

4.2(II) Correlation Analysis

To check the relationship among the variables, correlation analysis is made. The results of correlation analysis are depicted in the table. 
There is a Positive relationship between FDI and all four Independent variables. It shows that all four Variables are Significant with FDI.There is a positive and strong relationship between OP\&EI

\section{Table 4 -Regression}

Dependent Variable: FDI

Method: Least Squares

Sample: 1999M01 2013M12

Included observations: 180

\begin{tabular}{lrlll}
\hline \hline \multicolumn{1}{c}{ Variable } & Coefficient & Std. Error & t-Statistic & Prob. \\
\hline \hline CPI & -3.543373 & 0.492606 & -7.193123 & 0.0000 \\
EI & 1.926272 & 0.453884 & 4.243973 & 0.0000 \\
FE & $1.25 \mathrm{E}-08$ & $3.65 \mathrm{E}-09$ & 3.427544 & 0.0008 \\
OP & 8.804354 & 1.915549 & 4.596257 & 0.0000 \\
\hline \hline R-squared & 0.319787 & Mean dependent var & 160.6728 \\
Adjusted R-squared & 0.308193 & S.D. dependent var & 191.7802 \\
S.E. of regression & 159.5131 & Akaike info criterion & 13.00410 \\
Sum squared resid & 4478218. & Schwarz criterion & 13.07506 \\
Log likelihood & -1166.369 & Hannan-Quinn criter. & 13.03287 \\
Durbin-Watson stat & 1.275041 & & & \\
\hline \hline
\end{tabular}

The regression was performed in order to predict the FDI and four independent variables. The Most significant variable is for FDI highlighted by our regression result. (t-statistics 8.804 $\mathrm{p}=0.001$ ) followed by CPI (t-statistics $-3.54373, \mathrm{p}=0.0522)$. However, when the regression coefficient was compared for these significant variables, a contrasting difference was observed. The regression coefficient for EI and CPI are 1.92. This shows that $1 \%$ increase in FDI the CPI will also increase by $1 \%$. There is a Positive relationship with CPI and FDI.

The overall accuracy of regression model can further be investigated by observing the adjusted R2 values. This adjusted R2 (0.30) explains that by relying on EI and CPI, we can predict the overall trend accurately up to $46 \%$ which means that if we know the exact values over a period of time for EI and C then we can have an idea how FDI would behave or this can enable us to predict the FDI and this prediction would be $30 \%$ accurate based on our regression results. The variation in FDI is explained by all independent variables included in the model is $46 \%$. The remaining $54 \%$ variation is due to other factors that are not included in model. The higher value shows greater strength of model.

Table 5 - Corelation

\begin{tabular}{cccccc} 
& FDI & OP & EI & CPI & FE \\
\hline \hline FDI & 1.000000 & 0.258585 & 0.319935 & 0.062443 & 0.320254 \\
OP & 0.258585 & 1.000000 & 0.908637 & 0.855064 & 0.556776 \\
EI & 0.319935 & 0.908637 & 1.000000 & 0.877939 & 0.690712 \\
CPI & 0.062443 & 0.855064 & 0.877939 & 1.000000 & 0.598259 \\
FE & 0.320254 & 0.556776 & 0.690712 & 0.598259 & 1.000000
\end{tabular}




\section{Exchange rate (ER) and Foreign Direct Investment (FDI)}

The results of Regression shows that the coefficient of exchange rate is 3.63 that means when exchange rate increases by 1 unit the Foreign Direct Investment (FDI) will Increase by 3.63. There is positive relationship between Exchange rate and Foreign Direct Investment (FDI). This result is significant at $1 \%$ level of significance level. Shah and Ahmad (2003)

The co-efficient of Exchange Rate (ER) is 4.31 and its p-Value is $0.05 \%$ which shows significant relationship with FDI in Pakistan (Nasir et al. 2009)

\section{Energy Imports(EI) and Foreign Direct Investment (FDI)}

The co-efficient of energy imports (EI) is 4.10 and its p-Value is $0.05 \%$ shows significant relationship with FDI in Pakistan (Shamsuddin 1994, Mushtaq et al. 2012)

\section{Trade openness (OP) and Foreign Direct Investment (FDI)}

The co-efficient of Trade openness (OP) is 1.28 and its p-Value is $0.01 \%$ which shows significant relationship with FDI in Pakistan (Talat et al. 2013, Bakhtiar et al. 2010)

\section{Consumer Price Index (CPI) and Foreign Direct Investment (FDI)}

The co-efficient of Consumer Price Index (CPI) is -2.39 and its p-Value is less then $0.01 \%$ which shows insignificant relationship with FDI in Pakistan (Adeel et al. 2013)

\section{Summary}

The empirical results of all tests used in this study are presented and interpreted in this section. Next chapter describes the conclusion and recommendations of this study.

\section{CONCLUSION AND RECOMMENDATIONS}

The purpose of the study is to check the impact of Exhange Rate, trade openness and energy imports, on foreign direct investment in Pakistan using monthly time series data from 1999 to 2013 by employing multiple Cointegration analysis. The previous chapter described the results and their interpretation. This chapter summarizes the major findings, and limitations of this study. Further, this chapter gives the policy implication and recommendations for the future research.

\section{Discussion of major findings}

Table show the results of multiple regression analysis that indicate, in the previous literature some studies found positive and other found negative sign of the exchange rate with Foreign Direct Investment (FDI). This study shows the positive relation of the exchange rate with Foreign Direct Investment (FDI) in Pakistan during the study period 1999-2013. Further, Trade Opennes (OP) Energy Imports (EI) and Exchange Rate (ER) shows Positive relationship with Foreign Direct Investment. so support the literature studies (Bakhtiar et al. (2010), Nasir and Hassan (2011), Talat et al. (2013), Aqeel and Nishat (2004), Shamsuddin (1994), Ismail and Burak (2007)).

\section{Recommendations for future study}

The time period used in this study is from 1999 to 2013 (Monthly Basis) thefore, for the future, research can be done by extending time period of the study. Finaly, annual time series data is used in this study consisting four independent variables (exchange rate, Consumer Price Index, trade openness, and energy imports). Hence in the future, study can be made by using panel data and by droping the independent variables or by changing the methodology. 


\subsection{Policy implications}

Based on the findings, this study can be vauable for the policy makers, Government, and foreign investors so that the foreign direct investment should be increase in the Pakistan because it is very important of country growth and development.

\subsection{Limitation of the Study}

The data constraint (due to large data set i.e four independent variables, Excahnnge Rate , Consumer price Index, Trade Openness,energy imports, is the major limitation faced in this study, therefore this study is conducted from 1999 to 2013. Further, generalizability is another constraint of this study. Because this study is done by taking annual data set of the variables in Pakistan and it is a developing country having different political conditions.

\section{REFERENCES}

A.S. Adair, J.N. Berry and W.S. McGreal (1994) "Investment Decision Making: A Behavioral Perspective" Journal of Property Finance, Vol. 5 No. 4, pp. 32-42

Afzal Talat , Anwar Zeshan (2013) "Foreign Direct Investment (FOREIGN DIRECT INVESTMENT (FDI)) in Pakistan: Measuring Impact of Cost of War Against Terrorism, Political Instability and Electricity Generation" Caspian Journal of Applied Sciences Research, pp. 117-127

Alberto Alesina, Roberto Perotti (1993) "Income distribution, political instability and Investment" NBER Working Papers series

Benjamin Furlan et al (2012) "Democratization And Real Exchange Rates" Working Paper NO. 201206

Chingarande Anna (2012) "The impact of interest rates on foreign direct investment: A case study of the Zimbabwean economy" International Journal of Management Sciences and Business Research, 2012, Vol. 1, No. 5.

Carl Henrik Knutsen (2011) "The Economic Effects of Democracy and Dictatorship" Ph.D. Thesiss

Elaine Worzala, (1995) "Currency risk and international property investments" Journal of Property Valuation \& Investment, Vol. 13 No. 5, 1995, pp. 23-38

Edward Nketiah-Amponsah, Charles Barnor (2011) "Effects of Exchange Rate Regimes on FOREIGN DIRECT INVESTMENT (FDI) Inflows in Ghana" International Journal of Economics and Finance, Vol.3

Economic survey of Pakistan, various issues.

Ismail Cevis \& Burak Camurdan (2007) "The Economic Determinants of Foreign Direct Investment in Developing Countries and Transition Economies" The Pakistan Development Review, pp. 285-299

Hakro and Gumro (2011) "Determinants of Foreign Direct Investment Flows to Pakistan" The Journal of Developing Areas, Vol 44, No 2, pp. 217-242

International Financial Statistics, various issues

Jenny A. Minier (1998) "Democracy and Growth: Alternative Approaches" Journal of Economic Growth, pp 241-266

Kozo Kiyota, Shujiro Urata (2002). "Exchange rate volatility and Foreign Direct Investment".

Khalid Mahmood, Toseef Azid, Masood Mashkoor (2010) "Democracy and Economic Growth in Pakistan" Research Journal of International Studies, issue-15

Khalid Mahmood, Imran Sharif Chaudhary (2012) "National Savings, Investment and Institutional Freedoms in Pakistan" International journal of Asian Social Science, Vol.6, No.2, pp 782-789

Luis Serven (2002) "Real Exchange Rate Uncertainty and Private Investment in Developing Countries: The World Bank Policy Research Working Paper 2823.

Linda S. Goldberg "Exchange Rates and Foreign Direct Investment" Princeton Encyclopedia of the World Economy

Muhammad Arshad and Shujaat Ali (2011) "Foreign direct investment and economic growth in Pakistan: A Sectoral analysis" PIDE Working papers 2011-67 
Michael Bleaney, David Greenaway (2001) "The impact of terms of trade and real exchange Rate volatility on investment and growth in sub-Saharan Africa" Journal of Development Economics, Vol. 65 Z 2001. 491-500

Mahdi Safdari, Masood Soleymani (2011) "Exchange Rate uncertainty and Investment: Income of Middle East and North African countries" Global Economy and Finance journal, Vol, 4. $\mathrm{Pp}$ 60-73

Mohammad Hanif Akhtar "The Determinants of Foreign Direct Investment in Pakistan: An Econometric Analysis" The Lahore Journal of Economics, Vol.5, No.1

Muhammad Imtiaz Subhani, Zubair Lakhiya (2011) "The Structure and Performance of the economy of Pakistan (Comparative study between democratic and non democratic Governments)" International Journal of Business and social science, pp 241-246 Vol. 2

Mahr Muhammad Yousaf et al (2008) “Economic Evaluation Of Foreign Direct Investment In Pakistan" Pakistan Economic and Social Review Volume 46, No.1, pp. 37-56

Naveed Shahzad Muhammad Zahid "The Determinants of Foreign Direct Investment in Pakistan" Abasyn Journal of Social Sciences Vol. 5 No. 1

Olga M. Fuentes (2006) "Exchange rate volatility and Investment: Evidence at plant level"

Onuorah and Okoli (2013) "Long Run Relationship between Macroeconomic Variables and FOREIGN DIRECT INVESTMENT (FDI) in Nigeria" Developing Country Studies ISSN 2224-607X (Paper) ISSN 2225, Vol 3, No.1, 2013

Philippe Aghion, Philippe N Bacchetta, Romain Ranciere (2006) "Exchange Rate Volitality and productivity growth: The role of financial Development" NBER Working Paper series

Patrick Crowley, Jim Lee (2003) "Exchange rate volatility and Foreign investment: International Evidence" International Trade Journal, Vol XVII, No. 5

Peter Hooper and Steven W. Kohlhagen (1976) "The effect of exchange rate uncertainty on the prices and volume of international trade"

Robert S. Pindyck (1990) "Irreversibility, Uncertainty, and Investment"

Rajnish Mehra (1978). "On the Financing and investment decisions of Multinational Firms in the Presence of Exchange Risk" The Journal of financial and Quantitative Analysis, Vol. 13, No.2, pp No. 227-244

Stuart Landon and Constance E. Smith (2005) "Exchange Rates and Investment Good Prices: A Cross-Industry Comparison" Working Paper Series Paper No. 2005-08 3.pp. 304-312

Stuart and Constance E. Smith (2007) "Investment and Exchange rate: Short run and Long run Aggregate and sector level Estimates"

Savvakis C. Savvides (1994) "Risk Analysis in Investment Appraisal" Published in "Project Appraisal", Vol 9 pages 3-18State Bank of Pakistan, various issues of Statistical Bulletin

Zafar Mueen Nasir, Arshad Hassan (2011) "Economic Freedom, Exchange Rate stability and FOREIGN DIRECT INVESTMENT (FDI) in South Asia"www.satp.org 